\title{
Calcareous and agglutinated foraminifera ratio: Chemical interface tracer for Pliocene Chiahsien Paleoseep, SW Taiwan
}

\author{
Chih-Wei Chien ${ }^{1, *}$, Chi-Yue Huang ${ }^{2}$, Shang-De Luo ${ }^{1}$, Shao-Yong Jiang ${ }^{2}$, Chenhui Liu ${ }^{3}$, and \\ Kenn-Ming Yang ${ }^{1}$ \\ ${ }^{1}$ Department of Earth Sciences, National Cheng Kung University, Tainan City, Taiwan \\ ${ }^{2}$ School of Ocean and Earth Science, Tongji University, Shanghai, China \\ ${ }^{3}$ State Key Laboratory for Mineral Deposits Research, School of Earth Sciences and Engineering, Nanjing University, Nanjing,
} China

\section{Article history: \\ Received 28 May 2017 \\ Revised 29 November 2017 \\ Accepted 7 December 2017 \\ Keywords:}

Cold seep remnant, Foraminifera, Taphonomically active zone, Pliocene, Southwestern Taiwan

Citation:

Chien, C.-W., C.-Y. Huang, S.-D. Luo, S.-Y. Jiang, C. Liu, and K.-M. Yang, 2018: Calcareous and agglutinated foraminifera ratio: Chemical interface tracer for Pliocene Chiahsien Paleoseep, SW Taiwan. Terr. Atmos. Ocean. Sci.,29,417-428, doi: $10.3319 /$ TAO.2017.12.07.01

\begin{abstract}
Cold-seep carbonate concretions were preserved in the Chiahsien paleoseep remnant within the Pliocene Yenshuiken Formation of southwestern Taiwan foreland sequence. Compared to the non-seep controls in the Yenshuiken Formation, muddy host rocks that were $<30 \mathrm{~cm}$ from massive authigenic carbonate concretions (ACCs) have low $\mathrm{CaCO}_{3}$ contents $(\sim 1 \%)$, high percentages of agglutinated foraminifera $(\sim 90 \%)$, and almost no calcareous foraminifera (both benthic and planktonic). However, host rocks that were $>30 \mathrm{~cm}$ away from such ACCs have normal marine assemblages (low agglutinated foraminifera percentages, $<6.6 \%$; fair $\mathrm{CaCO}_{3}$ content, $3.5-7.9 \%)$. Host rocks that were $<80 \mathrm{~cm}$ from chimney-shaped ACCs also have abnormal assemblages, whereas those $>80 \mathrm{~cm}$ away from the chimneys have normal assemblages. Host rocks between pipe-shaped ACCs have similar characteristics to mudstone samples from control sites. Low percentages of calcareous foraminiferal fossils in the paleoseep remnant are due to pore water acidification within the taphonomically active zone (TAZ), which is triggered and accelerated by oxidation of sulfide $\left[\mathrm{HS}^{-}\right.$, the product of anaerobic oxidation of methane (AOM)] in the methane seep environments. We suggest that foraminiferal assemblages can be influenced by methane seep activities taphonomically and that, therefore, ratios between calcareous and agglutinated foraminifera can reflect and record geochemical interface [e.g., TAZ; sulfate-methane interface (SMI) where AOM occurs] shifts on a subtler scale (only few decimeters) in paleoseep remnants.
\end{abstract}

\section{INTRODUCTION}

Cold seeps are particular geological phenomena due to discharge of geofluids from the sea floor (Judd and Hovland 2007). In methane seeps, excess methane $\left(\mathrm{CH}_{4}\right)$ is anaerobically oxidized by sulfate $\left(\mathrm{SO}_{4}^{2-}\right)$ via the syntrophic consortia of methanotrophic archaea and sulfate-reducing bacteria (Boetius et al. 2000). This microbial process, anaerobic oxidation of methane $(\mathrm{AOM})$, produces bicarbonate $\left(\mathrm{HCO}_{3}{ }^{-}\right)$ and hydrogen sulfide ( $\left.\mathrm{HS}^{-}\right)^{-}$. As bicarbonate is produced, the elevated alkalinity accelerates the precipitation of authigenic carbonates (Aharon 2000; Lein 2004). In modern and ancient cold seep sites, authigenic carbonates form in

\footnotetext{
* Corresponding author

E-mail:blattus@gmail.com
}

several patterns, such as chimneys, pipes, crusts, blocks, and mounts, with or without remarkable chemosymbiotic fauna (e.g., Vesicomyid, Lucinid, and Solemyid bivalves, galatheid crab and vestimentiferan tubeworms; Sibuet and Olu 1998; Levin 2005; Campbell 2006; Liu et al. 2008).

In methane cold seeps, excess methane decreases dissolved oxygen (DO) of pore water. Though anoxic sediments seem to benefit preservation of calcareous fossils (Berkeley et al. 2007), the redox zone tends to be sharp and shallow in the sediments; in other words, higher AOM activities form a sulfate-methane interface (SMI; sensu Borowski et al. 1996). If AOM activity is strong enough to produce a sufficient amount of sulfide to support chemosymbiontic fauna, they would induce DO-rich seawater into sulfide-rich sediments 
for their symbiontic sulfide-oxidizing bacteria (e.g., tubeworms, Lucinid, and Solemyid bivalves; Dubilier et al. 2008). Cai et al. (2006) mentioned that such behavior will produce a wider acidified zone - that is, a wider taphonomically active zone (TAZ). According to the observations in a petroleum seep (Cai et al. 2006) and bacterial mats of sulfide-oxidizing bacteria Beggiatoa (Preisler et al. 2007), the pH value may obviously change in only several centimeters' depth under the sediment-water interface. Cai et al. (2006) further predicted that $\mathrm{pH}$ value should change more intensely in cold seep sites where a lot of authigenic carbonates form.

Therefore, the preservation of calcareous fossils in cold seeps depends on the competition between two geochemical conditions: anaerobic/reducing for preservation versus oxic/ acidifying for dissolution. Many cold seep infauna prefer to live near the redox interface (e.g., Lucinids; see Taylor and Glover 2000). Survival of their calcareous tests from acidified pore water depends on the detention time within TAZ: longer detention, more dissolution (Cai et al. 2006). The cold seep macrofossils often represent a paradoxical occurrence: completely dissolved shells with well-preserved carbonate inner-moulds [e.g., most Anodontia goliath (Yokoyama 1928) fossils in the Chiahsien Paleoseep; see Chien et al. 2013].

Foraminifera are important members of marine benthic and planktonic meiofauna (Armstrong and Brasier 2004). Previous studies on recent and ancient cold seeps reveal that there are no endemic foraminiferal species of the seep fauna and agglutinated taxa were negligible (Barbieri and Panieri 2004; Martin et al. 2007; Panieri et al. 2009). Abundances and diversities of foraminiferal seep fauna are controversially various worldwide (see Panieri et al. 2009 and references therein). However, there was no detailed sampling and/or observation revealing how foraminiferal fauna change (abruptly or as transitional process) between seep and non-seep sites. Additionally, carbonate dissolution was common above SMI due to acid-generating aerobic oxidation of reduced chemical species (e.g., $\mathrm{H}_{2} \mathrm{~S}$ ) (Cai et al. 2006), but the effect of acidified fluids onto foraminiferal fauna remains unclear.

Based on the seep carbonates and their stable carbon isotope signatures, we have recorded a paleoseep in the Pliocene foredeep sequences of southwestern Taiwan (Chien et al. 2013). This study will present influences of pore water chemistry, which is associated with methane seep activity, on foraminiferal taphonomy by short-interval (few decimeters) sampling.

\section{GEOLOGICAL SETTING}

Taiwan island is the result of arc-continent collision between the Philippine Sea Plate and the Eurasian plate (Huang et al. 2000; Fig. 1). In the western part of the island, the active fold-and-thrust belt (the Western Foothills Zone; WFZ) is composed of Miocene shelf-slope to PliocenePleistocene foreland basins deposits (Lin et al. 2003) and
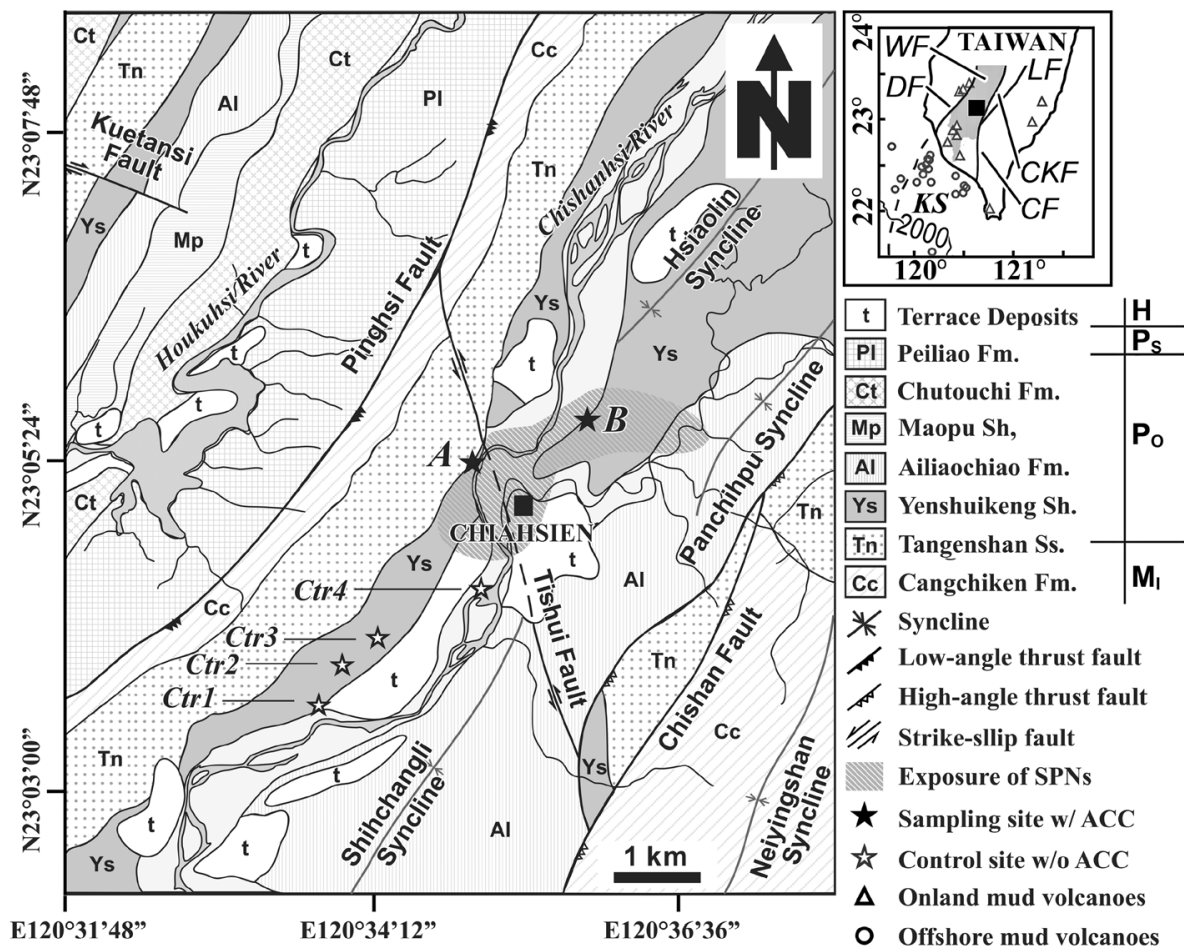

Fig. 1. Geological map of Chiahsien area, SW Taiwan (after Sung et al. 2000) and mud volcano locations onshore (Shih 1967) and offshore (Chiu et al. 2006). Two outcrops (A \& B) are also shown in Fig. 2. ACC: authigenic carbonate concretions; WF: Western Foothills; KS: Kaoping Slope; LF: Lishan Fault; CKF: Chukou Fault; CF: Chishan Fault; DF: deformation front. 
has been incorporated into accretionary prisms during the arc-continent collision in the last 2 million years (Ma) (Liu et al. 1998; Huang et al. 2000). Large amounts of organic materials and terrestrial sediments derive from the exposed accretionary prism to the offshore area of southwestern Taiwan and accelerate the formation and accumulation of hydrocarbon geofluids at the offshore Kaoping Slope. There are many active mud volcanoes, mud diapirs, and gas seepages within the Kaoping Slope and its onshore northward extension (i.e., southern part of WFZ) (Yang et al. 2004; Chiu et al. 2006; Chen et al. 2010; Sun et al. 2010) (Fig. 1).

A remarkable paleoseep remnant is located in the Chiahsien District, southeastern Taiwan. It is preserved in the foreland basin sequence within the southern part of WFZ (Fig. 1). Rock strata appearing at the paleoseep outcrops were from the Late Miocene Tangenshan Sandstone to the Pliocene Yenshuikeng Shale (Chung 1962) (Figs. 1, 2). Trace fossil analysis indicated that the depositional environments changed from inner shelf to outer shelf in the early Pliocene (Ting et al. 1991; Yeh and Chang 1991). Tectonostratigraphic research also revealed that a rapid subsidence event with a distance of ca. $272 \mathrm{~m}$ during 4.4 - 4 Ma occurred in the distal area of the southwestern Taiwan foreland basin (Yang et al. 2014).

The outcrops containing paleoseep carbonates were totally within the Yenshuikeng Shale, which is surrounded by the Pinghsi Fault and the Chishan Fault and crossed by the Tishui Fault (Fig. 1). Based on field investigation of their occurrence patterns, three types of the seep carbonate were recognized (please see Chien et al. 2013 for details):

(1) Massive brecciated blocks (MBBs; typically $2-4 \mathrm{~m}$ long, $1-2 \mathrm{~m}$ wide, and $3-5 \mathrm{~m}$ high; $\delta^{13} \mathrm{C}$ : -49.6 to $-38.2 \%$ ) are large, whitish gray to grayish yellow colored, mound-shaped carbonate bodies, with or without vent and pipe structures, in exposure A along the Chih- shanhsi River (Fig. 2). Chemosymbiotic lucinid pelecypod A. goliath (Yokoyama 1928) fossils were found within MBBs.

(2) Giant chimneys (GCs; each ca. 2 - $5 \mathrm{~m}$ wide and $30 \mathrm{~m}$ high; $\delta^{13} \mathrm{C}$ : -43.1 to $-17.7 \%$ ) are large and thick cylindrical or fusiform concretions developing upwardly perpendicular to bedding in exposure A (Fig. 2). They occur either in isolation or parallel to each other and contain of vent/pipe structures (diameter $>15 \mathrm{~cm}$ ) clustered with irregular shaped carbonates. Abundant in situ A. goliath (Yokoyama 1928) fossils occurred in the margin of one large fusiform GC body (size: ca. $5 \mathrm{~m} \times 5 \mathrm{~m} \times 10 \mathrm{~m}$ ).

(3) Slender pipe networks (SPNs; $\delta^{13} \mathrm{C}:-43.5$ to $+5.9 \%$ ) are composed of elongated small carbonate cylinders with a diameter commonly $5-15 \mathrm{~cm}$. They occur both in exposures $\mathrm{A}$ and $\mathrm{B}$, and the bank of the Chihshanhsi River (Figs. 1, 2). The "pipes" develop upwardly perpendicular to the host mudstone bedding, typically separate from each other by $1-2 \mathrm{~m}$, and some are branched or connected horizontally with the same pipes. We also found a few lucinid fossils Lucinoma annulata (Reeve 1850) together with some pipes.

\section{METHODS AND MATERIALS}

We collected 39 muddy host rock samples for foraminiferal fauna, $\mathrm{CaCO}_{3}$ content, and carbon and oxygen stable isotopic analysis, including three series of samples (M1 M7, G1 - G6, and S1 - S6) with sampling intervals between 10 - $40 \mathrm{~cm}$, except samples M7 and G6, which are $1 \mathrm{~m}$ from the former sample (Figs. 2, 3a-c). Both G- and M-series samples were collected from proximal to distal from huge authigenic carbonate concretions (ACCs) along bedding plane (Figs. 3a, b). Sixteen supplementary samples, which were collected directionally between MBB concretions

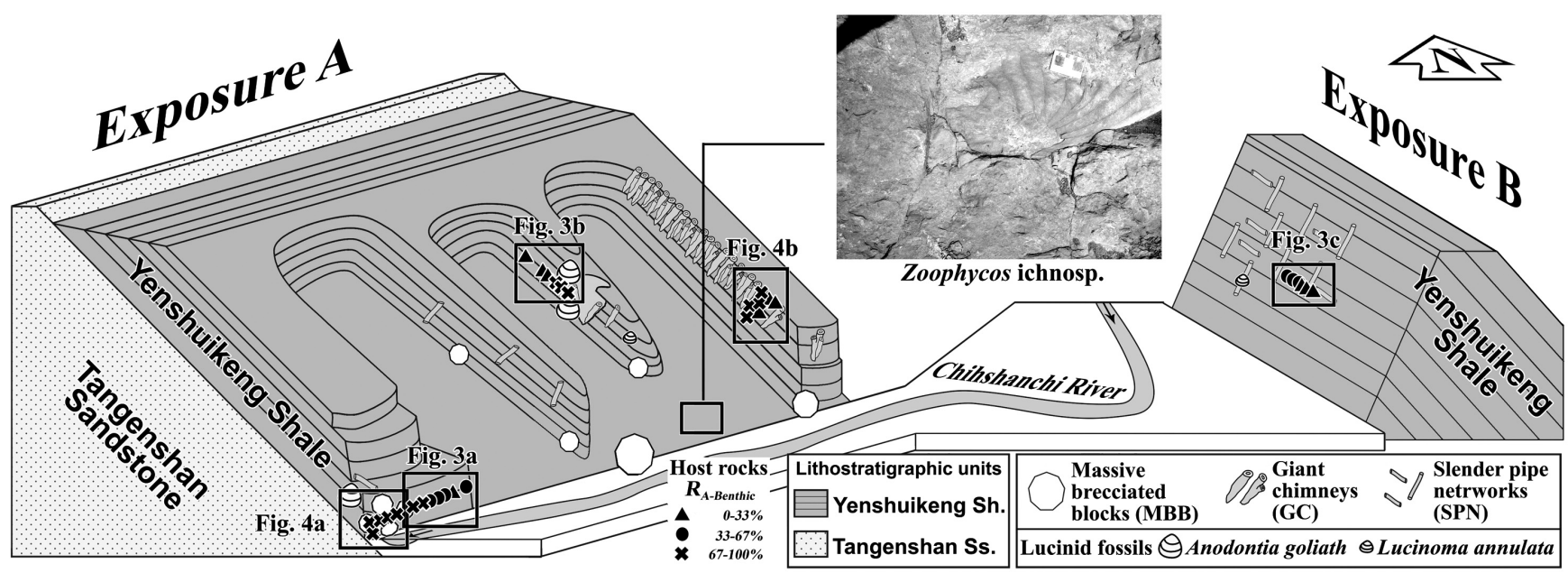

Fig. 2. Semi-schematic diagram of studied outcrops, distribution of three types of seep carbonates and licinid fossils, and sampling locations of host rocks. The attitude of strata is $\mathrm{N} 40^{\circ} \mathrm{E}, 35^{\circ} \mathrm{E}$. Dip angle and distance are not in scale. 

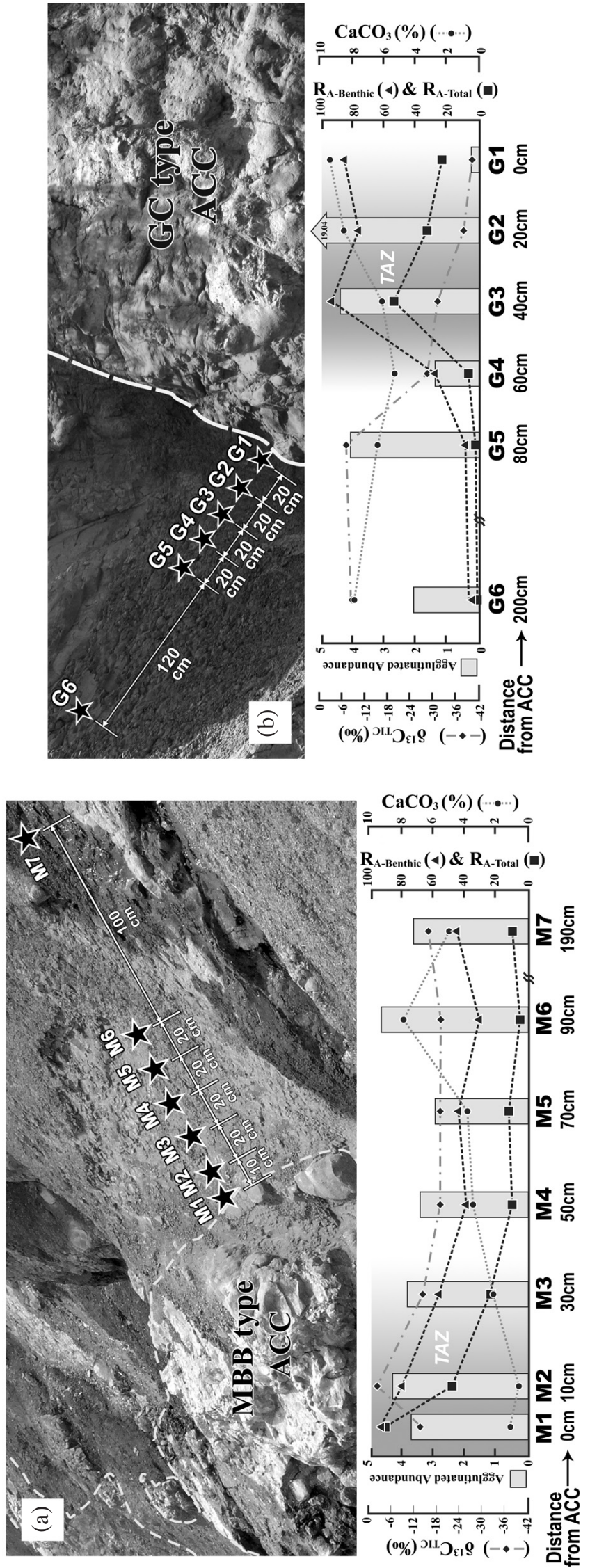

$\mathrm{CaCO}_{3}(\%)(\cdots \bullet \cdots)$
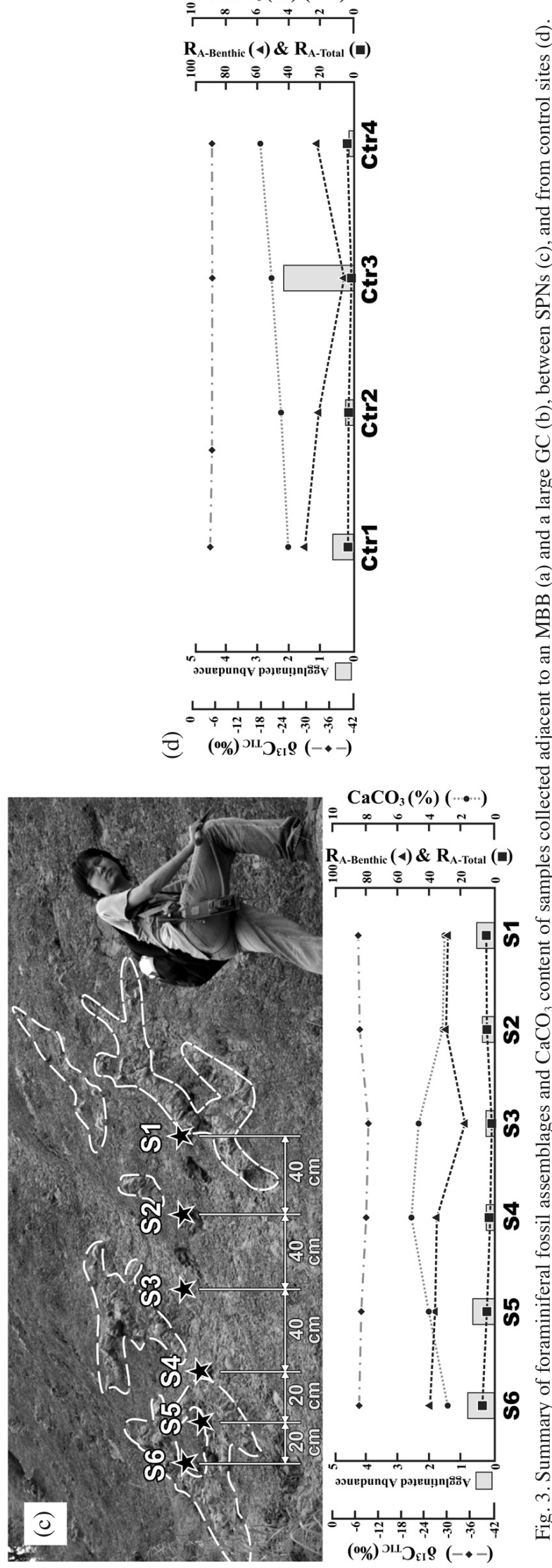
(CH01 - CH07) or randomly around GC concretions (CH08 - CH16) (Figs. 2 - 4) during our initial field surveys, are also presented in this paper.

\subsection{Foraminiferal Fossils}

According to their life styles, foraminifera are classified mainly into planktonic and benthic. All planktonic foraminifera have calcareous tests, whereas benthic foraminifera may have calcareous or agglutinated tests. In a normal marine milieu above a carbonate compensation depth, foraminifera with calcareous tests dominate total assemblages (Armstrong and Brasier 2004). The foraminiferal species in this study are merely classified into three groups, based on their wall materials of test and life styles. All agglutinated species (abbreviated as "A") belong to the Order Textulariida; all planktonic species (abbreviated as "P") belong to the Order Globigerinida; and the remaining calcareous benthic species (abbreviated as "C") mostly belong to the Order Ro- taliida, with a few species belonging to the Order Lagenida and Miliolida (Table 1). Even though the taxonomic rank is too high and too rough for detailed foraminiferal paleoecological researches, it is enough to simply and rapidly screen the taphonomic and geochemical zones and interfaces in the Chiahsien Paleoseep.

For foraminifer faunal counting, $200 \mathrm{~g}$ of each host mudstone samples was washed and sieved, and foraminifera fossils in the $>150 \mu \mathrm{m}$ residues were picked until all foraminifera were picked or at least 300 individuals were counted. The percentage of agglutinated foraminifera of each sample was represented as $\mathrm{R}_{\mathrm{A}-\text { Total }}$ (ratio of agglutinated to total foraminiferal specimens):

$\mathrm{R}_{\mathrm{A}-\text { Total }}=\left[\mathrm{N}_{\mathrm{A}} /\left(\mathrm{N}_{\mathrm{P}}+\mathrm{N}_{\mathrm{C}}+\mathrm{N}_{\mathrm{A}}\right)\right] \times 100$

and $\mathrm{R}_{\mathrm{A}-\mathrm{Benthic}}$ (ratio of agglutinated foraminiferal specimens to benthic foraminiferal specimens):
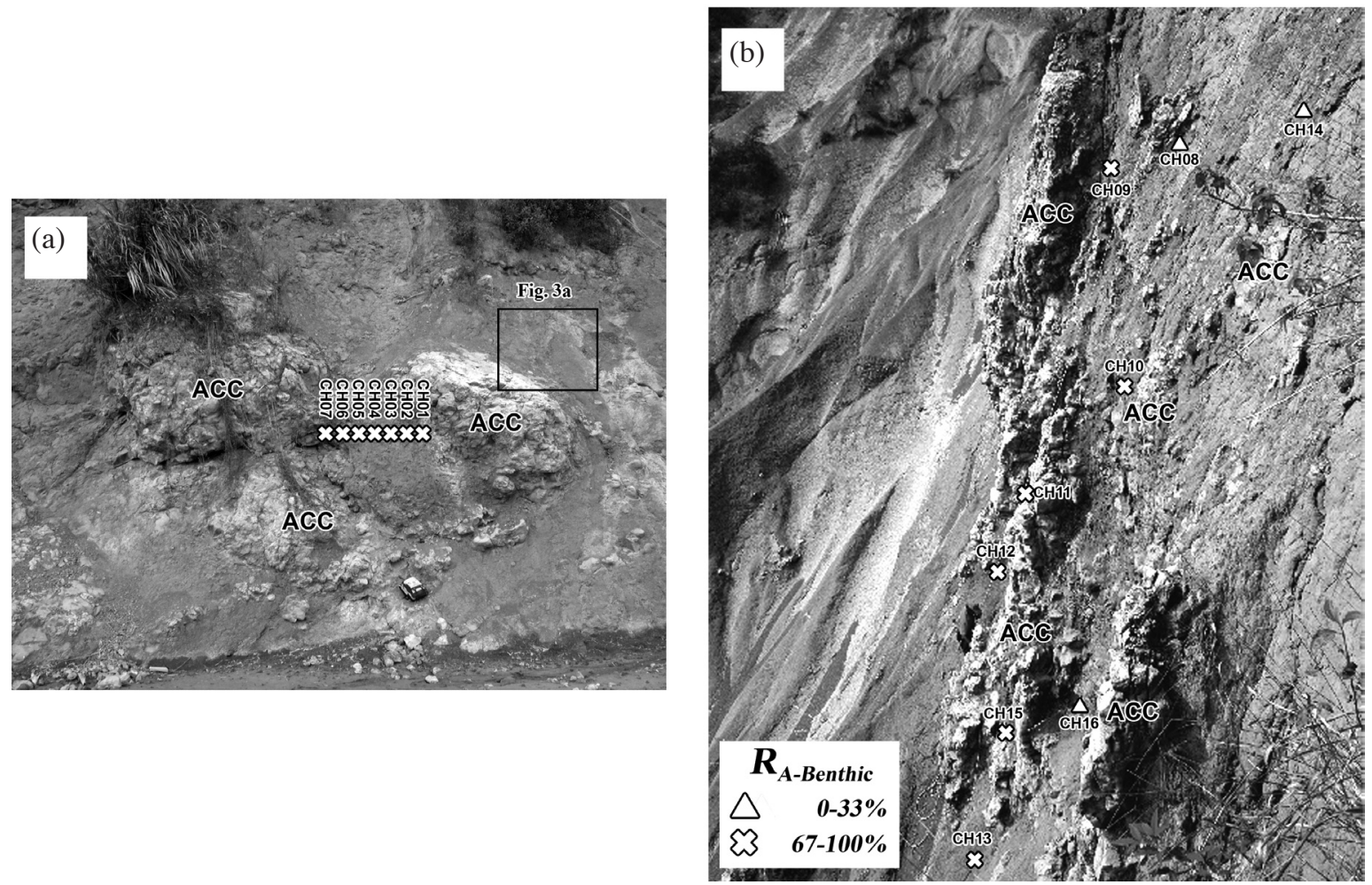

Fig. 4. Supplementary samples between MBB concretions (a) or surrounding GC concretions (b). ACC: authigenic carbonate concretions.

Table 1. The generalized foraminiferal classification.

\begin{tabular}{c|c|c|c}
\hline Abbreviation & Life Style & Wall composition & Taxonomical adscription \\
\hline P & Planktonic & Calcareous (mostly low-magnesium calcite) & Globigerinida \\
\hline C & \multirow{2}{*}{ Benthic } & Calcareous (often high-magnesium calcite; aragonite of some species) & Rotaliida, Lagenida and Miliolida \\
\cline { 3 - 4 } & & Agglutinated (mostly arenaceous in this study) & Textulariida \\
\hline
\end{tabular}




$$
\mathrm{R}_{\mathrm{A} \text {-Benthic }}=\left[\mathrm{N}_{\mathrm{A}} /\left(\mathrm{N}_{\mathrm{C}}+\mathrm{N}_{\mathrm{A}}\right)\right] \times 100
$$

$\mathrm{N}_{\mathrm{P}}, \mathrm{N}_{\mathrm{C}}$, and $\mathrm{N}_{\mathrm{A}}$ are the counts of planktonic, calcareous benthic, and agglutinated foraminifera in a sample, respectively. Abundance of foraminiferal fossils is shown by the number of individuals compared to the weight of a sample. We only counted specimens with a proloculus (the first chamber), because some elongated benthic foraminifera are easily broken into several pieces. For example, for Bathysiphon-like species (elongated forms), it is difficult to determine their proloculus and they were thus excluded from numerical analysis. Therefore, percentages of agglutinated foraminifera were somewhat underestimated. The degree of underestimation is hard to evaluate, because the certain counts of entire tests of Bathysiphon-like species are unknown.

\subsection{Calcium Carbonate Contents}

Total carbon (TC) concentrations of powdered host rock samples (10 mg each) were measured by high temperature $\left(1150^{\circ} \mathrm{C}\right)$ catalytic combustion. Total organic carbon (TOC) concentrations were measured from separate samples (10 mg each), which were acidified by $10 \%$ phosphoric acid $\left(\mathrm{H}_{3} \mathrm{PO}_{4}\right)$ and heated for $4 \mathrm{~h}$ at $150^{\circ} \mathrm{C}$. The measurements of TC and TOC were made using a Lachat IL 550TOC-TN Analyzer at Department of Earth Sciences, National Cheng Kung University. Total inorganic carbon (TIC) concentrations were calculated from the difference between the TC and the TOC:

$\operatorname{TIC}(\%)=\operatorname{TC}(\%)-\operatorname{TOC}(\%)$

and calcium carbonate contents were calculated by the equation:

$\mathrm{CaCO}_{3}(\%)=\mathrm{TIC} \times 8.33$

\subsection{Isotopic Analyses of Inorganic Carbon}

Isotopic analyses for inorganic carbon of host rock samples were made using a Finnigan Delta Plus XP mass spectrometer coupled to the Gas Bench II device at the State Key Laboratory for Mineral Deposits Research of Nanjing University. Samples (15 g each) were powdered and washed by hydrogen peroxide solution (35\%) for removing organic matter. Oxygen and carbon isotopic compositions of TIC are shown as delta values per mil $(\%)$ and related to the Pee Dee Belemnite (PDB) Standard, with China's GBW00405 carbonate standards (TTB-1) for calibration. The 1 standard deviation of repeated sample measurements was less than 0.16 and $0.13 \%$ for $\delta^{13} \mathrm{C}$ and $\delta^{18} \mathrm{O}$, respectively.

\section{RESULTS}

\subsection{Agglutinated Foraminiferal Percentages}

Calcareous taxa dominate foraminiferal assemblages in the Yenshuikeng Shale of control sites. Planktonic species dominate total assemblages $(\geq 75.42 \%)$, whereas agglutinated benthic species are subordinate to total assemblages $(\leq 4.93 \%)$ and benthic assemblages $(\leq 33.33 \%)$ (Fig. 3d; Table 2). In the Chiahsien Paleoseep, however, percentage of calcareous tests dramatically decreases nearby the large MBB and GC concretions at distances of 10 and $40 \mathrm{~cm}$, respectively (Figs. 2, 3a, b). Agglutinated tests dominate in the host rocks adjacently surrounding MBBs (sample M1and M2; $\mathrm{R}_{\mathrm{A} \text {-Total }} \geq 48.31 \% ; \mathrm{R}_{\mathrm{A} \text {-Benthic }} \geq 80.83 \%$ ) but reach their normal proportions of outer shelf (Planktonic percentages: $81.92 \%$; RA-Total: 5.86\%; sensu Armstrong and Brasier 2004) at $90 \mathrm{~cm}$ away from MBBs (sample M6; Fig. 3a; Table 2). A similar phenomenon was found near GCs; however, the sample (G3) with maximum $R_{A \text {-Total }}$ (49.22\%) and $\mathrm{R}_{\mathrm{A}-\mathrm{Benthic}}(94.42 \%)$ is $\sim 40 \mathrm{~cm}$ away from a GC concretion; samples beyond $70 \mathrm{~cm}$ (G5 and G6) represent low $\mathrm{R}_{\text {A-Total }}(0.75-1.91 \%)$ and low $\mathrm{R}_{\text {A-Benthic }}(4.68$ - 9.14\%) (Fig. 3b; Table 2). Mudstones between SPNs represent high planktonic percentages $(>82.45 \%$ ), low $\mathrm{R}_{\mathrm{A} \text {-Total }}$ values $(\leq 7.27 \%)$, and moderate $\mathrm{R}_{\mathrm{A} \text {-Benthic }}$ values (18.7 - 41.4\%) (Figs. 2, 3c; Table 2).

Though we only counted benthic foraminifera of the supplementary samples (i.e., only $\mathrm{R}_{\mathrm{A}-\text { Benthic }}$ values are available), they represent an extremely bimodal distribution of the $\mathrm{R}_{\mathrm{A} \text {-Benthic }}$ values: $\geq 95.74 \%$ and $\leq 31.03 \%$ (Figs. 2, 4; Table 2). All MBB samples (CH01 - CH07) and six of nine samples near GCs (CH09 - CH13, CH15) have extremely high $\mathrm{R}_{\mathrm{A} \text {-Benthic }}$ values, whereas three samples near GCs (CH08, CH14, and CH16) indicate similar $\mathrm{R}_{\mathrm{A}-\text { Benthic }}$ values to the control samples.

\section{2 $\mathrm{CaCO}_{3}$ Contents of Host Mudstones}

Control samples picked from non-seep parts of the Yenshuikeng Shale have $\mathrm{CaCO}_{3}$ content of 4.2 - 5.9\% (average $5.0 \%$; Fig. 3d), consistent with modern shelf-slope sediments $\left(\mathrm{CaCO}_{3}: 1.5\right.$ - 5.5\%), offshore southwestern Taiwan (Sheu and Huang 1989).

The $\mathrm{CaCO}_{3}$ contents of two host rock samples (M1 and M2) close to a MBB concretion are very low (1.0 and $0.5 \%$, respectively), whereas the samples M6 and M7, which are > $100 \mathrm{~cm}$ away from the same concretion, have normal marine $\mathrm{CaCO}_{3}$ percentages (Fig. 3a; Table 2). Samples G1 and G2, which are close to a huge GC concretion, have very high $\mathrm{CaCO}_{3} \%$ (28.2 and $17.7 \%$, respectively). Even the sample $180 \mathrm{~cm}$ away from the same GC concretion (G6) contains $\mathrm{CaCO}_{3}(9.8 \%)$ higher than the control samples. Remarkably, sample $\mathrm{G} 3$ has a sharply declined $\mathrm{CaCO}_{3}$ value $(7.7 \%)$ and the highest $\mathrm{R}_{\mathrm{A} \text {-Benthic }}(94.42 \%)$ and $\mathrm{R}_{\mathrm{A} \text {-Total }}(49.22 \%)$ among the 
Table 2. Faunal overview, $\mathrm{CaCO}_{3}$ contents, and oxygen and carbon isotopic compositions of TIC of host rock and control samples.

\begin{tabular}{|c|c|c|c|c|c|c|c|}
\hline Sample & Agglutinatedabundance $^{*}$ & Planktonic $^{\dagger}(\%)$ & $\mathbf{R}_{\text {A-Total }}(\%)$ & $\mathbf{R}_{\mathrm{A}-\mathrm{Benthic}}(\%)$ & $\mathrm{CaCO}_{3}(\%)$ & $\delta^{13} \mathbf{C}_{\mathrm{TIC}^{\S}}(\%)$ & $\left.\delta^{18} \mathbf{O}_{\mathrm{TIC}^{8}}{ }^{(\% o}\right)$ \\
\hline \multicolumn{8}{|c|}{ Control samples } \\
\hline Ctr1 & 0.2 & 88.53 & 3.82 & 33.33 & 4.27 & -3.5 & -9.2 \\
\hline $\mathrm{Ctr} 2$ & 2.2 & 83.99 & 3.84 & 23.98 & 4.75 & -3.9 & -8.9 \\
\hline $\mathrm{Ctr} 3$ & 0.3 & 75.42 & 2.15 & 8.75 & 5.25 & -3.7 & -9.3 \\
\hline Ctr4 & 0.7 & 82.13 & 4.93 & 25.36 & 5.97 & -3.8 & -9.4 \\
\hline \multicolumn{8}{|c|}{ Host mudstone closed to MBB type concretions } \\
\hline M1 & 3.72 & 4.35 & 89.86 & 93.94 & 1.03 & -13.3 & -6.8 \\
\hline M2 & 4.30 & 40.22 & 48.31 & 80.83 & 0.56 & -1.8 & -8.4 \\
\hline M3 & 3.86 & 58.85 & 23.71 & 57.61 & 2.14 & -14.0 & -6.2 \\
\hline M4 & 3.42 & 74.31 & 10.26 & 39.95 & 3.48 & -18.5 & -5.5 \\
\hline M5 & 2.98 & 71.61 & 12.78 & 45.02 & 3.83 & -18.6 & -5.4 \\
\hline M6 & 4.66 & 81.92 & 5.86 & 32.41 & 7.86 & -18.7 & -5.1 \\
\hline M7 & 3.62 & 77.42 & 10.45 & 46.29 & 4.98 & -15.5 & -5.9 \\
\hline $\mathrm{CH} 1^{*}$ & & & & 100.00 & 1.68 & -24.6 & -3.7 \\
\hline $\mathrm{CHO}_{2}^{\ddagger}$ & & & & 99.40 & 15.13 & -39.8 & 0.0 \\
\hline $\mathrm{CHO3}^{\ddagger}$ & & & & 98.67 & 7.02 & -35.6 & -0.8 \\
\hline $\mathrm{CHO}_{4}$ & & & & 99.64 & 8.54 & -36.0 & -0.8 \\
\hline $\mathrm{CH} 05^{\circ}$ & & & & 100.00 & 15.30 & -37.1 & 0.0 \\
\hline $\mathrm{CH} \mathrm{C}^{\ddagger}$ & & & & 98.81 & 9.91 & -37.0 & -0.6 \\
\hline $\mathrm{CH} 7^{*}$ & & & & 95.74 & 15.05 & -36.3 & -0.9 \\
\hline \multicolumn{8}{|c|}{ Host mudstone closed to GC type concretions } \\
\hline G1 & 0.2 & 73.22 & 23.37 & 86.00 & 28.20 & -40.2 & 0.3 \\
\hline G2 & 19.0 & 57.67 & 32.60 & 77.02 & 17.71 & -38.0 & -0.4 \\
\hline G3 & 4.4 & 47.87 & 49.22 & 94.42 & 7.70 & -31.0 & -2.2 \\
\hline G4 & 1.4 & 77.11 & 6.55 & 28.66 & 6.66 & -28.4 & -3.9 \\
\hline G5 & 4.1 & 79.10 & 1.91 & 7.11 & 9.14 & -7.0 & -6.9 \\
\hline G6 & 2.1 & 84.04 & 0.75 & 4.68 & 9.88 & -8.4 & -7.9 \\
\hline $\mathrm{CH} 08^{\ddagger}$ & & & & 20.07 & 5.53 & -19.5 & -5.2 \\
\hline $\mathrm{CH} 09$ & & & & 98.68 & 7.53 & -33.7 & -1.9 \\
\hline $\mathrm{CH} 10^{\ddagger}$ & & & & 100.00 & 1.98 & -29.2 & -3.9 \\
\hline $\mathrm{CH} 11^{\ddagger}$ & & & & 99.15 & 11.88 & -39.4 & -0.4 \\
\hline $\mathrm{CH} 12$ & & & & 99.03 & 23.85 & -39.2 & 0.0 \\
\hline $\mathrm{CH} 13^{\ddagger}$ & & & & 100.00 & 6.09 & -38.8 & -1.7 \\
\hline $\mathrm{CH} 14$ & & & & 31.03 & 7.99 & -20.1 & -3.5 \\
\hline $\mathrm{CH} 15^{\circ}$ & & & & 100.00 & 0.69 & -33.6 & -1.5 \\
\hline $\mathrm{CH} 16^{+}$ & & & & 27.03 & 3.20 & -13.7 & -6.0 \\
\hline \multicolumn{8}{|c|}{ Host mudstone between SPN type concretions } \\
\hline $\mathrm{S} 1$ & 0.5 & 86.48 & 4.01 & 29.67 & 2.99 & -5.9 & -9.3 \\
\hline $\mathrm{S} 2$ & 0.3 & 87.44 & 3.88 & 30.91 & 3.08 & -6.3 & -8.7 \\
\hline S3 & 0.2 & 94.67 & 1.00 & 18.70 & 4.68 & -8.3 & -8.6 \\
\hline S4 & 0.2 & 91.82 & 3.03 & 37.04 & 5.18 & -7.9 & -9.7 \\
\hline S5 & 0.7 & 89.22 & 4.09 & 37.93 & 3.99 & -6.3 & -9.1 \\
\hline S6 & 0.8 & 82.45 & 7.27 & 41.41 & 2.87 & -6.1 & -8.9 \\
\hline
\end{tabular}

Note: $\neq$ : Shaded samples are supplementary samples.

*: Agglutinated abundance: agglutinated foraminiferal individual numbers per gram of sample.

$\dagger:$ Planktonic\%: planktonic foraminiferal percentage to total assemblage.

$\S: \delta^{13} C_{T I C} \& \delta^{18} O_{T I C}$ : also plotted in Fig. 4. 
GC series samples, and sample G4 next to G3 has the lowest $\mathrm{CaCO}_{3} \%$ (6.7\%) (Fig. 3b; Table 2). The $\mathrm{CaCO}_{3}$ contents of the samples between SPNs are all similar to or slightly less than the control samples (2.9 - 5.2\%; Fig. 3c; Table 2).

The calcium carbonate contents of the supplementary samples represent a random distribution (Table 2). Most samples among MBBs (CH02 - CH07) have high to extremely high $\mathrm{CaCO}_{3}$ contents $(7.0-15.3 \%)$, except $\mathrm{CHO1}$, which has a very low concentration of $\mathrm{CaCO}_{3}(1.7 \%)$. For samples surrounding GCs, four samples (CH09, CH11, CH12, and $\mathrm{CH} 14)$ have high percentages of $\mathrm{CaCO}_{3}(\geq 7.5 \%)$, two samples ( $\mathrm{CH} 08$ and $\mathrm{CH} 13)$ have similar values of $\mathrm{CaCO}_{3}(5.5$ and $6.1 \%)$ to control samples, and three samples $(\mathrm{CH} 10, \mathrm{CH} 15$, and $\mathrm{CH} 16)$ have low content of $\mathrm{CaCO}_{3}(0.7-3.2 \%)$.

\subsection{Carbon Isotopic Compositions of Total Inorganic Carbon of Host Rocks}

We analyzed carbon isotopic compositions of TIC of host rock samples (Fig. 3; Table 2) in order to check whether authigenic carbonate micrites exist within host rocks around seep carbonates. Their $\delta^{18} \mathrm{O}_{\mathrm{TIC}}$ and $\delta^{13} \mathrm{C}_{\mathrm{TIC}}$ show good correlations between two end-members: methane-derived carbonates $\left(\delta^{13} \mathrm{C}<-40 \%\right)$ and controls $\left(\delta^{13} \mathrm{C}:-3.7 \pm 0.2 \%\right.$ ) (Fig. 5). Calcium carbonate contents represent apparent correlations to $\delta^{13} \mathrm{C}_{\mathrm{TIC}}$ among the $\mathrm{M}$ - and $\mathrm{G}$-series samples (higher $\mathrm{CaCO}_{3} \%$, lower $\delta^{13} \mathrm{C}_{\mathrm{TIC}}$; Fig. 3). Among the host rock TIC concentrations, which are apparently ${ }^{13} \mathrm{C}$-depeleted, samples around type MBB concretions (M1, M3 - M7) represent somewhat higher $\delta^{13} \mathrm{C}_{\mathrm{TIC}}$ (-18.7 to $-13.3 \%$; Fig. 3a), whereas samples around type GC concretions (G1 - G4) represent lower $\delta^{13} \mathrm{C}_{\text {TIC }}$ (-40.2 to $-28.4 \%$; Fig. $3 \mathrm{~b}$ ) and narrower distribution range. Low $\delta^{13} \mathrm{C}_{\text {TIC }}$ values of G1 - G4 apparently indicate that methane-derived micritic authigenic carbonates had precipitated within these host mudstone samples (Fig. 3b).

\section{DISCUSSION}

\subsection{Seep-Influenced Foraminiferal Fossil Assemblages and $\mathrm{CaCO}_{3}$ Contents}

In the control samples and low $\mathrm{R}_{\mathrm{A} \text {-Total }}$ samples, high planktonic/benthic ratios are commonly found, as well as in the modern cases at the offshore southeastern Asia continent and southwestern Taiwan (Wang et al. 1985; Fan 1991), and is consistent with the depositional environment interpretation according to the Zoophycos ichnofacies within the Yenshuikeng Shale (Ting et al. 1991). We also observed some Zoophycos ichnosp. from outcrop A of the Chiahsien Paleoseep (Fig. 2).

In the Chiahsien Paleoseep, there are several samples (M1 - M5, G1 - G3) representing an extremely high proportion of agglutinated species (Figs. 2, 3a, b; Table 2). The phenomenon of predomination of agglutinated foraminifera is dissimilar to other studies for modern seep foraminiferal fauna, which noted less proportion of agglutinated species in seep sites compared to non-seep sites (Heinz et al. 2005; Panieri and Sen Gupta 2008; Martin et al. 2010). Though agglutinated foraminiferal abundances of the samples from outcrop A are slightly higher than those from outcrop B and control sites (Fig. 3; Table 2), no apparent changes are

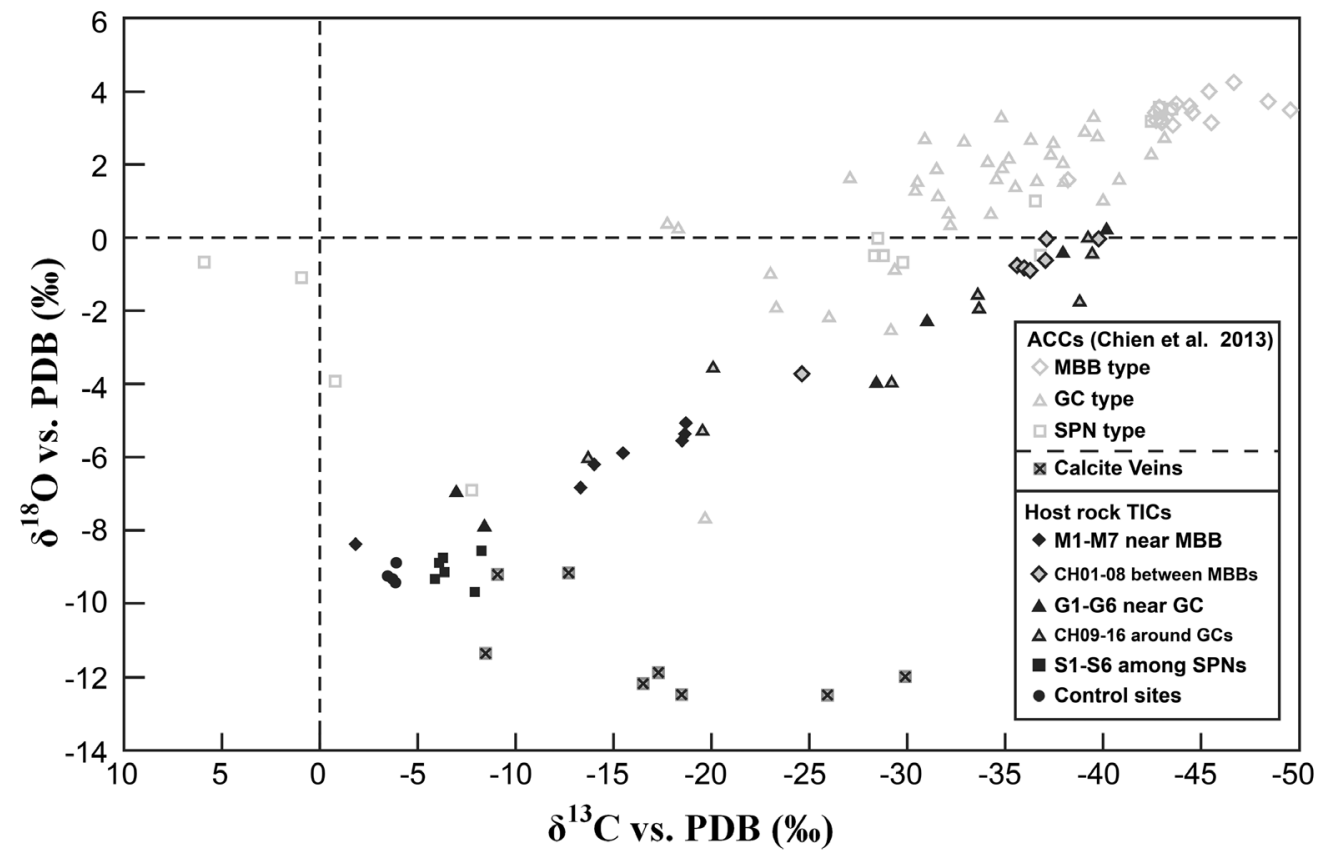

Fig. 5. The plot of $\delta^{18} \mathrm{O}$ versus $\delta^{13} \mathrm{C}$ for the three types of authigenic carbonates, calcite veins (from Chien et al. 2013), and TIC of host rock and control samples (this study; Fig. 3 and Table 2). 
shown between abnormally high $\mathrm{R}_{\mathrm{A} \text {-Total }}$ and normal samples in the same series of samples (e.g., comparison between samples M1 - M2 and M6, or between G3 and G5; Figs. 3a, b; Table 2). Because each series of samples is at the same bedding plane and the samples are very close to each other (Figs. 3a - c), any differences between foraminiferal assemblages of the same series of samples should be due to extremely local taphonomic conditions rather than geological, sedimentological, or paleoecological effects. Deposition of turbidity currents is not localized laterally in the scale of meters or few-tens-of-meters, and calcareous tests also cannot be selectively removed by turbidity currents. Seasonal variability of foraminiferal fauna does not present in the same horizon (i.e., the same time/season) and may be not recorded in the time-averaged fossil assemblages. Therefore, we consider that the high agglutinated ratios were caused by dissolution of carbonates via chemical processes of seepage activities (e.g., Cai et al. 2006). In contrast, the percentage of agglutinated tests shows no apparent changes nearby SPNs (Figs. 2, 3c). Because the size of a seep carbonate may have a reasonable correlation to the flux and quantity of methane release (Chien et al. 2013), we suggest that foraminiferal fossil assemblages were not affected by weak and small (SPN type) seepages.

If dissolution of calcareous materials had taken place, we can speculate that the host rock samples with high $\mathrm{R}_{\text {A-Total }}$ or high $\mathrm{R}_{\text {A-Benthic }}$ should contain low percentages of $\mathrm{CaCO}_{3}$. Samples M1, M2 - M5, CH01, CH10, and CH15 accord with this speculation (Fig. 3a; Table 2), which implies a longer detention time within TAZ (i.e., higher dissolution of carbonates). However, $\mathrm{CaCO}_{3}$ content does not always directly reflect the dissolution of calcareous tests in our observations. For example, G1 and G2 have extremely high percentages of $\mathrm{CaCO}_{3}$ but abnormally high $\mathrm{R}_{\mathrm{A} \text {-Benthic }}$ and slightly high $\mathrm{R}_{\mathrm{A} \text {-Total }}$ (Fig. 3b; Table 2). Many supplementary samples with extremely high $\mathrm{R}_{\mathrm{A}-\mathrm{B} e n t h i c}(\mathrm{CH02}-\mathrm{CH} 07, \mathrm{CH} 09$, CH11 - CH13) also have abnormally high $\mathrm{CaCO}_{3} \%$.

\subsection{Isotopic Signature for Precipitation and Dissolution of Carbonates}

There are two major source of TIC within the host rock samples: biogenic carbonate (e.g., calcareous foraminiferal tests) and methane-derived micritic authigenic carbonates. In non-seep sites (i.e., control sites), biogenic carbonates should predominate TIC compositions; whether they underwent diagenetic alterations or not, their $\delta^{13} \mathrm{C}$ values are not less than $-3.9 \%$ in this study (Fig. 3d; Table 2). In contrast, methane-derived authigenic carbonates have very low $\delta^{13} \mathrm{C}$ values, which are typically less than -30\%o (Campbell 2006). Therefore, the samples in which biogenic carbonates were highly dissolved (i.e., in which they have extremely high $\mathrm{R}_{\mathrm{A} \text {-Benthic }}$ and high $\mathrm{R}_{\mathrm{A} \text {-Total }}$ values) and micritic authigenic carbonates precipitated should have extremely low $\delta^{13} \mathrm{C}_{\mathrm{TIC}}$ values $(<-30 \%)$. For example, samples with extremely high $\mathrm{R}_{\mathrm{A}-\text { Benthic }}(\mathrm{G} 1$ - G3, CH02 - CH07, CH09, CH11 - CH13) have apparently low $\delta^{13} \mathrm{C}_{\mathrm{TIC}}$ values (even similar to the ACCs) (Figs. 3a, b; Table 2). Samples that have $\delta^{13} \mathrm{C}_{\mathrm{TIC}}$ value between control samples and samples with ${ }^{13} \mathrm{C}$-depleted TIC may represent various degrees of mixtures of biogenic carbonates and authigenic carbonates (Fig. 5; Table 2).

$\mathrm{M}$-series samples (except M2) have low $\delta^{13} \mathrm{C}_{\mathrm{TIC}}$ values. The $\delta^{13} \mathrm{C}$ values of MBBs are the lowest among all authigenic carbonate samples (Fig. 5), and the micritic authigenic carbonate around MBBs should be their precursor (i.e., they should have the lowest $\delta^{13} \mathrm{C}$ values). However, $\delta^{13} \mathrm{C}_{\mathrm{TIC}}$ values of the M-series samples are higher than those of samples G1 - G4 (these G-samples have higher $\mathrm{R}_{\mathrm{A} \text {-Total }}$ than controls). We suggest that the weaker seep activity when MBBs formed also led to lower precipitation rates of micritic authigenic carbonate within the host sediments. Therefore, lower $\mathrm{CaCO}_{3}$ contents per unit volume of host rocks around $\mathrm{MBBs}$ represent higher $\delta^{13} \mathrm{C}_{\mathrm{TIC}}$ values than the host rocks around GCs. A more closed milieu among MBBs (samples $\mathrm{CHO} 2$ - CH07; Fig. 4a) concentrated the geofluids, and more micritic authigenic carbonate could precipitate there; thus, these samples have high percentages of $\mathrm{CaCO}_{3}$ and very low $\delta^{13} \mathrm{C}_{\mathrm{TIC}}$ values.

\subsection{Dissolution and Acid Resistance of Biogenic Carbonates}

Dissolution of calcareous materials is a crucial taphonomic process for preservation of foraminiferal tests. Essentially, preservation of calcareous tests is controlled by carbonate saturation of pore water in the host sediments. Temperature, $\mathrm{pH}$ value, salinity, and dissolved $\mathrm{CO}_{2}$ content of pore water are all possible parameters affecting the solubility of carbonates. The calcareous foraminiferal tests are usually dissolved within the oxic sediments, especially in the intertidal environments (Berkeley et al. 2007), or in the abyssal environment below the carbonate compensation depth; in contrast, calcareous tests are generally well-preserved in the anoxic condition (Berkeley et al. 2007). However, if excess sulfide (HS-) formed by AOM accumulates (in Fe-depleted sediments, pyrite is difficult to form, and $\mathrm{HS}^{-}$shall increase), $\mathrm{pH}$ value of pore water may be dramatically descending due to oxidization of HS:

$\mathrm{HS}^{-}+2 \mathrm{O}_{2} \rightarrow \mathrm{SO}_{4}{ }^{2-}+\mathrm{H}^{+}$

which causes dissolution of calcareous tests of foraminifera and mollusks (Martin 1999; Murray 2006).

Biogenic carbonates usually belong to one of three mineral species: aragonite, low-magnesium calcite (LMC; Mg content: 1 - 4 mol\%), or high-magnesium calcite (HMC; Mg content: 11 - 19 mol\%); the ranking of acid resistance 
is LMC > aragonite > HMC (Morse and Mackenzie 1990; Martin 1999). Molluscan shells are mainly composed of aragonite, LMC, or mixed-layers of the two; planktonic foraminiferal tests are mostly composed of LMC; calcareous benthic foraminiferal tests are mainly composed of HMC (a few species are composed of aragonite) (Martin 1999). Thus, the ranking of acid resistance should be planktonic foraminifera $\geq$ bivalves $\geq$ benthic foraminifera. Test sizes and microtextures (e.g., numbers of pores and arrangement of mineral grains) also influence acid resistance among different taxa and even among different individuals of the same species (Martin 1999). Because foraminiferal tests are usually small and porous (especially planktonic), they may be more sensitive to acidified conditions than bivalve shells are.

We found that three samples (M3, G1 - G2) have very high $\mathrm{R}_{\mathrm{A}-\text { Benthic }}$ but fair $\mathrm{R}_{\mathrm{A}-\mathrm{Total}}$, which means that planktonic foraminiferal tests still dominate such fossils assemblages. This phenomenon reflects a bias of dissolution of calcareous foraminiferal tests due to the differences of acid resistance between planktonic and benthic foraminifera. Even a foraminiferal fossil assemblage could not stay in a TAZ as long as possible to dissolve all calcareous tests, dissolution of carbonates had taken place and calcareous benthic foraminiferal tests were prone to dissolve prior to planktonics. In other words, fossil assemblages in a paleoseep site with very high $\mathrm{R}_{\mathrm{A} \text {-Benthic }}$ but fair $\mathrm{R}_{\mathrm{A} \text {-Total }}$ indicate a rapid shift or a decline of a TAZ.

In this study, we found a series of time slices around the large-sized ACCs, which represents a progressive shifting of redox front and carbonate budget in the paleoseep: biogenic carbonates (e.g., Lucinid shells and calcareous foraminiferal tests) were dissolved within the seepage-triggered TAZ (sensu Davies et al. 1989; Cai et al. 2006); followed by bypassing of releasing hydrocarbons further away from the previously built GC concretion. TAZ and SMI simultaneously shifted in the same directions; therefore micritic authigenic carbonate started to precipitate at the same place where calcareous tests had been dissolved (Fig. 3b). Declination of seepage activity retards the shifting of TAZ and SMI; thus, calcareous tests would stay within TAZ for a longer duration and are further dissolved in such conditions (Cai et al. 2006). This explains that the sample with the highest $\mathrm{R}_{\mathrm{A} \text {-Benthic }}$ and $\mathrm{R}_{\mathrm{A} \text {-Total }}(\mathrm{G} 3$ ) would have the lowest percentage of $\mathrm{CaCO}_{3}$ finally.

In summary, pore water chemistry can override other ecological and taphonomical factors (e.g., benthic patchiness; time-average effect; Murray 2006) to influence foraminiferal fauna only around venting outlets, where intensity and flux of methane emission were ample, to produce seep-type fossil assemblages with high $\mathrm{R}_{\mathrm{A} \text {-Total }}$ and high $\mathrm{R}_{\mathrm{A} \text {-Benthic }}$. There would be normal fauna elsewhere even in a very short distance (just tens of centimeters to a few meters) from the vents in a cold seep site. Therefore, position and compactness of sampling determine results of foraminiferal researches of paleoseeps.

\section{CONCLUSIONS}

Foraminiferal fossils in the Chiahsien Paleoseep represent various assemblages from normal middle-to-outer-shelf fauna to seep fauna. In seep fauna, calcareous foraminiferal tests were dissolved within the TAZ if higher flux of methane occurred. Even though in a high taxonomic rank (order), foraminifera can serve as powerful indicators for screening the shifting of geochemical interfaces (e.g., TAZ and SMI) in a subtler scale of only decimeters in cold seep remnants.

While inconsistency of worldwide seep foraminiferal fauna is derived from complexities of substrate, ecology, and geochemistry of respective seeps, our study can provide a complicated and comparable reference for other ancient (and probably also for modern) seep foraminifer studies. Cold seeps do affect foraminiferal assemblages at least in the case of diagenetic alteration. A bias of preservation of agglutinated foraminifera should occur in the ancient seep remnants with large ACCs; however the influence of seep activities onto foraminiferal assemblages (live and dead) may be sufficient only in a small range next to seep outlets or conduits. Therefore, ascertainment of seep-influenced foraminiferal assemblages depends on sampling position, compactness, and distance to seep outlets, conduits, or ACCs.

Acknowledgements This study was supported by a grant (NSC94-2116-M-006-005) from the National Science Council, Taiwan. We thank Dr. Duo-Fu Chen for his discussions. We also appreciate Mr. Te-Wei Lin's and Mr. Yen-Jun Lin's help in our field survey. We are grateful to two anonymous reviewers for their constructive and helpful comments.

\section{REFERENCES}

Aharon, P., 2000: Microbial processes and products fueled by hydrocarbons at submarine seeps. In: Riding, R. E. and S. M. Awramik (Eds.), Microbial Sediments, Springer, Berlin, Heidelberg, 270-281, doi: 10.1007/978-3-662-04036-2_29. [Link]

Armstrong, H. A. and M. D. Brasier, 2004: Foraminifera. Microfossils, Second Edition, Blackwell Publishing, Malden, MA USA, 142-187, doi: 10.1002/9781118685440.ch15. [Link]

Barbieri, R. and G. Panieri, 2004: How are benthic foraminiferal faunas influenced by cold seeps? Evidence from the Miocene of Italy. Palaeogeogr. Palaeoclimatol. Palaeoecol., 204, 257-275, doi: 10.1016/S00310182(03)00730-2. [Link]

Berkeley, A., C. T. Perry, S. G. Smithers, B. P. Horton, and K. G. Taylor, 2007: A review of the ecological and taphonomic controls on foraminiferal assemblage development in intertidal environments. Earth-Sci.Rev., 83, 205-230, doi: 10.1016/j.earscirev.2007.04.003. [Link]

Boetius, A., K. Ravenschlag, C. J. Schubert, D. Rickert, F. Widdel, A. Gieseke, R. Amann, B. B. Jørgensen, 
U. Witte, and O. Pfannkuche, 2000: A marine microbial consortium apparently mediating anaerobic oxidation of methane. Nature, 407, 623-626, doi: 10.1038/35036572. [Link]

Borowski, W. S., C. K. Paull, and W. Ussler, 1996: Marine pore-water sulfate profiles indicate in situ methane flux from underlying gas hydrate. Geology, 24, 655658, doi: 10.1130/0091-7613(1996)024<0655:mpwsp i $>2.3 . c 0 ; 2$. [Link]

Cai, W.-J., F. Chen, E. N. Powell, S. E. Walker, K. M. Parsons-Hubbard, G. M. Staff, Y. Wang, K. A. Ashton-Alcox, W. R. Callender, and C. E. Brett, 2006: Preferential dissolution of carbonate shells driven by petroleum seep activity in the Gulf of Mexico. Earth Planet. Sci. Lett., 248, 227-243, doi: 10.1016/j.epsl.2006.05.020. [Link]

Campbell, K. A., 2006: Hydrocarbon seep and hydrothermal vent paleoenvironments and paleontology: Past developments and future research directions. Palaeogeogr. Palaeoclimatol. Palaeoecol., 232, 362-407, doi: 10.1016/j.palaeo.2005.06.018. [Link]

Chen, S.-C., S.-K. Hsu, C.-H. Tsai, C.-Y. Ku, Y.-C. Yeh, and Y. Wang, 2010: Gas seepage, pockmarks and mud volcanoes in the near shore of SW Taiwan. Mar. Geophys. Res., 31, 133-147, doi: 10.1007/s11001-0109097-6. [Link]

Chien, C.-W., C.-Y. Huang, H.-C. Lee, and K.-M. Yang, 2013: Patterns and sizes of authigenic carbonate formation in the Pliocene foreland in southwestern Taiwan: Implications of an ancient methane seep. Terr. Atmos. Ocean. Sci., 24, 971-984, doi: 10.3319/ TAO.2013.07.05.01(TT). [Link]

Chiu, J.-K., W.-H. Tseng, and C.-S. Liu, 2006: Distribution of gassy sediments and Mud volcanoes offshore southwestern Taiwan. Terr. Atmos. Ocean. Sci., 17, 703722, doi: 10.3319/TAO.2006.17.4.703(GH). [Link]

Chung, C.-T., 1962: Geology of the Hunghuatzu anticline, Kaohsiung, Taiwan. Petrol. Geol. Taiwan, 1, 31-50.

Davies, D. J., E. N. Powell, and R. J. Stanton, 1989: Relative rates of shell dissolution and net sediment accumulation - a commentary: Can shell beds form by the gradual accumulation of biogenic debris on the sea floor? Lethaia, 22, 207-212, doi: 10.1111/j.1502-3931.1989. tb01683.x. [Link]

Dubilier, N., C. Bergin, and C. Lott, 2008: Symbiotic diversity in marine animals: The art of harnessing chemosynthesis. Nat. Rev. Microbiol., 6, 725-740, doi: 10.1038/ nrmicro1992. [Link]

Fan, W. C., 1991: Distribution of recent benthic foraminifers off southwestern Taiwan. Master Thesis, $96 \mathrm{pp}$.

Heinz, P., S. Sommer, O. Pfannkuche, and C. Hemleben, 2005: Living benthic foraminifera in sediments influenced by gas hydrates at the Cascadia convergent margin, NE Pacific. Mar. Ecol. Prog. Ser., 304, 77-89, doi: 10.3354/meps304077. [Link]
Huang, C.-Y., P. B. Yuan, C.-W. Lin, T. K. Wang, and C.-P. Chang, 2000: Geodynamic processes of Taiwan arc-continent collision and comparison with analogs in Timor, Papua New Guinea, Urals and Corsica. Tectonophysics, 325, 1-21, doi: 10.1016/S00401951(00)00128-1. [Link]

Judd, A. and M. Hovland, 2007: Seabed Fluid Flow: The Impact on Geology, Biology and the Marine Environment, Cambridge University Press, Cambridge, 492 pp, doi: 10.1017/CBO9780511535918. [Link]

Lein, A. Y., 2004: Authigenic carbonate formation in the ocean. Lithol. Miner.Resour., 39, 1-30, doi: 10.1023/B :LIMI.0000010767.52720.8f. [Link]

Levin, L. A., 2005: Ecology of cold seep sediments: Interactions of fauna with flow, chemistry and microbes. In: Gibson, R. N., R. J. A. Atkinson, and J. D. M. Gordon (Eds.), Oceanography and Marine Biology - An Annual Review, Vol. 43, Crc Press-Taylor \& Francis Group, Boca Raton, 1-46.

Lin, A. T., A. B. Watts, and S. P. Hesselbo, 2003: Cenozoic stratigraphy and subsidence history of the South China Sea margin in the Taiwan region. Basin Res., 15, 453478, doi: 10.1046/j.1365-2117.2003.00215.x. [Link]

Liu, C.-S., S.-Y. Liu, S. E. Lallemand, N. Lundberg, and D. L. Reed, 1998: Digital elevation model offshore Taiwan and its tectonic implications. Terr. Atmos. Ocean. Sci., 9, 705-738, doi: 10.3319/ TAO.1998.9.4.705(TAICRUST). [Link]

Liu, C.-S., S. Morita, Y.-H. Liao, C.-Y. Ku, H. Machiyama, S. Lin, and W. Shoh, 2008: High-resolution seismic images of the Formosa Ridge off Southwestern Taiwan where "hydrothermal" chemosynthetic community is present at a cold seep site. Proceedings of the 6th International Conference on Gas Hydrates (ICGH 2008), Vancouver, British Columbia, Canada, doi: 10.14288/1.0041106. [Link]

Martin, R. A., E. A. Nesbitt, and K. A. Campbell, 2007: Carbon stable isotopic composition of benthic foraminifera from Pliocene cold methane seeps, Cascadia accretionary margin. Palaeogeogr. Palaeoclimatol. Palaeoecol., 246, 260-277, doi: 10.1016/j. palaeo.2006.10.002. [Link]

Martin, R. A., E. A. Nesbitt, and K. A. Campbell, 2010: The effects of anaerobic methane oxidation on benthic foraminiferal assemblages and stable isotopes on the Hikurangi Margin of eastern New Zealand. Mar. Geol., 272, 270-284, doi: 10.1016/j.margeo.2009.03.024. [Link]

Martin, R. E., 1999: Taphonomy: A Process Approach, Cambridge University Press, Cambridge, 508 pp, doi: 10.1017/CBO9780511612381. [Link]

Morse, J. W. and F. T. Mackenzie, 1990: Geochemistry of Sedimentary Carbonates, 1st Edition, Elsevier Science Publishers B.V., Amsterdam, 707 pp. 
Murray, J. W., 2006: Ecology and Applications of Benthic Foraminifera, Cambridge University Press, Cambridge, 426 pp, doi: 10.1017/CBO9780511535529. [Link]

Panieri, G. and B. K. Sen Gupta, 2008: Benthic Foraminifera of the Blake Ridge hydrate mound, Western North Atlantic Ocean. Mar. Micropaleontol., 66, 91-102, doi: 10.1016/j.marmicro.2007.08.002. [Link]

Panieri, G., A. Camerlenghi, S. Conti, G. A. Pini, and I. Cacho, 2009: Methane seepages recorded in benthic foraminifera from Miocene seep carbonates, Northern Apennines (Italy). Palaeogeogr. Palaeoclimatol. Palaeoecol., 284, 271-282, doi: 10.1016/j.palaeo.2009.10.006. [Link]

Preisler, A., D. de Beer, A. Lichtschlag, G. Lavik, A. Boetius, and B. B. Jørgensen, 2007: Biological and chemical sulfide oxidation in a Beggiatoa inhabited marine sediment. The ISME Journal, 1, 341-353, doi: 10.1038/ ismej.2007.50. [Link]

Reeve, L. A., 1850: Monograph of the genus Lucina. In: Reeve, L. A. (Ed.), Conchologia Iconica, Vol. 6, 11 pp.

Sheu, D.-D. and C.-Y. Huang, 1989: Carbonate and organic carbon sedimentation on the continental margin off Southeastern Taiwan. Geo-Mar. Lett., 9, 45-51, doi: 10.1007/bf02262817. [Link]

Shih, T.-T., 1967: A survey of the active mud volcanoes in Taiwan and a study of their types and the character of the mud. Petrol. Geol. Taiwan, 5, 259-311.

Sibuet, M. and K. Olu, 1998: Biogeography, biodiversity and fluid dependence of deep-sea cold-seep communities at active and passive margins. Deep-Sea Res. Part II-Top. Stud. Oceanogr., 45, 517-567, doi: 10.1016/ S0967-0645(97)00074-X. [Link]

Sun, C.-H., S.-C. Chang, C.-L. Kuo, J.-C. Wu, P.-H. Shao, and J.-N. Oung, 2010: Origins of Taiwan's mud volcanoes: Evidence from geochemistry. Jour. Asian Earth Sci., 37,
105-116, doi: 10.1016/j.jseaes.2009.02.007. [Link]

Sung, Q.-C., C.-W. Lin, W .-H. Lin, and W.-C. Lin, 2000: Geologic map and explanatory text of Taiwan scale 1:50,000, sheet 51, Chiahsien, Central Geological Survey, MOEA, Taiwan.

Taylor, J. D. and E. A. Glover, 2000: Functional anatomy, chemosymbiosis and evolution of the Lucinidae. Geol. Soc. Lond. Spec. Publ., 177, 207-225, doi: 10.1144/ GSL.SP.2000.177.01.12. [Link]

Ting, H. H., C. Y. Huang, and L. C. Wu, 1991: Paleoenvironments of the Late Neogene sequences along the Nantzuhsien River, southern Taiwan. Petrol. Geol. Taiwan, 26, 121-149.

Wang, P., Q. Min, and Y. Bian, 1985: Foraminiferal biofacies in the northern continental shelf of the South China Sea. In: Wang, P. (Ed.), Marine Micropaleontology of China, China Ocean Press and Springer-Verlag Berlin Heidelberg, 151-175.

Yang, K.-M., J.-C. Wu, E.-W. Cheng, Y.-R. Chen, W.-C. Huang, C.-C. Tsai, J.-B. Wang, and H.-H. Ting, 2014: Development of tectonostratigraphy in distal part of foreland basin in southwestern Taiwan. J. Asian Earth Sci., 88, 98-115, doi: 10.1016/j.jseaes.2014.03.005. [Link]

Yang, T. F., G.-H. Yeh, C.-C. Fu, C.-C. Wang, T.-F. Lan, H.-F. Lee, C.-H. Chen, V. Walia, and Q.-C. Sung, 2004: Composition and exhalation flux of gases from mud volcanoes in Taiwan. Environ. Geol., 46, 10031011, doi: 10.1007/s00254-004-1086-0. [Link]

Yeh, M. G. and Y. L. Chang, 1991: The ichnofacies study of the Ailiaochiao Formation-the Changchihkeng Formation Chiahsien-Meinung Area, Kaohsiung. Petrol. Geol. Taiwan, 26, 151-181.

Yokoyama, M., 1928: Mollusca from the oil-field of the Island of Taiwan. Rep. Imp. Geol. Surv. Japan, 101, 1-112. 